\title{
H2AC7 Gene
}

National Cancer Institute

\section{Source}

National Cancer Institute. H2AC7 Gene. NCI Thesaurus. Code C162895.

This gene is involved in nucleosome assembly. 